Volume: 6

Nomor : 4

Bulan : November

Tahun : 2020

\title{
Peran Pendidikan Islam dalam Menanggulangi Fenomena Crosshijabers
}

\author{
Nur Fatimah \\ Ilmu Hamimah \\ Universitas Islam Zainul Hasan Genggong \\ Pos-el: nurfatimahsholeh@gmail.com
}

\section{DOI: 10.32884 /ideas.v6i4.285}

\begin{abstract}
Abstrak
Keberadaan crosshijabers yang dianggap sebagai personal atau komunitas yang mendapat pelabelan negatif dari masyarakat. Fenomena crosshijabers meresahkan masyarakat karena dianggap sebagai penyimpangan orientasi dalam ranah seksual dan dapat memicu tindak pidana. Penelitian ini dilakukan untuk mengetahui kedudukan pendidikan Islam dalam menanggulangi fenomena crosshijabers. Metode library research dengan pendekatan kualitatif deskriptif dipilih untuk mencapai tujuan atas penelitian ini. Melalui penelitian ini ditemukan bahwa pendidikan Islam memiliki peran yang signifikan dalam menanggulangi fenomena ini. Islam yang menjadi agama mayoritas dan banyaknya lembaga pendidikan Islam di Indonesia menjadikan pendidikan Islam perlu andil yang besar dalam menanggulangi fenomena ini. Selain itu, dalam Islam juga terdapat larangan penyerupaan antara lelaki dan perempuan. Sehingganya, dengan dilandasakan Alquran dan Hadis, pendidikan Islam dapat mengambil peranannya dalam menanggulangi fenomena crosshijabers dengan lebih menekankan batasan-batasan antara lelaki dan perempuan dalam kajian Alquran Hadis maupun dalam kajian fikih.
\end{abstract}

\section{Kata Kunci}

Pendidikan Islam, crosshijabers

\begin{abstract}
The existence of crosshijabers are considered as personal or community members who receive negative labeling from society. The phenomenon of crosshijabers is unsettling for the public because it is considered a deviation in sexual orientation and can trigger criminal acts. This research was conducted to determine the position of Islamic education in overcoming the crosshijabers phenomenon. The library research method with a descriptive qualitative approach was chosen to achieve the objectives of this study. Through this research, it was found that Islamic education has a significant role in overcoming this phenomenon. Islam, which is the majority religion and the number of Islamic education institutions in Indonesia, makes Islamic education a big part of overcoming this phenomenon. In addition, in Islam there is also a prohibition on the equality of men and women. So that, based on the Alquran and Hadis, Islamic education can take its role in overcoming the phenomenon of crosshijabers by emphasizing the boundaries between men and women in the study of the Alquran Hadis and in the study of Fiqih.
\end{abstract}

Keywords

Islamic education, crosshijabers

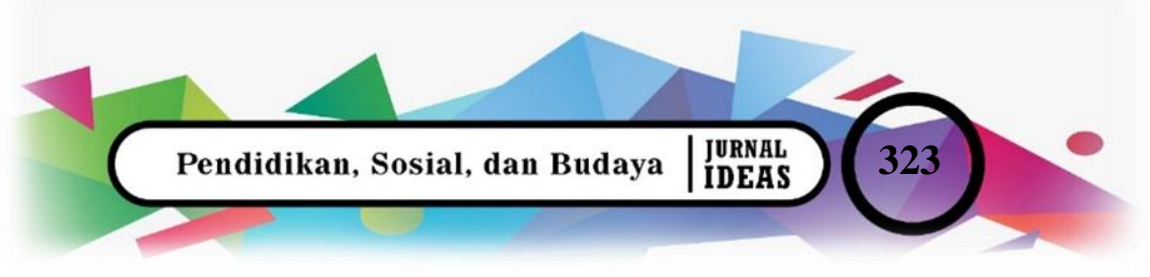


7. E-ISSH: 2656-940X

(7) P-ISSH: 2442-367K

URL:jurnal.ideaspublishing.co.id
Volume: 6

Nomor : 4

Bulan : November

Tahun : 2020

\section{Pendahuluan}

Fenomena crosshijabers menghebohkan media sosial dan publik pada akhir Desember tahun 2019. Crosshijabers adalah sebuah komunitas para pria yang berpakaian layaknya wanita berhijab dan bercadar. Warga masyarakat cukup diresahkan dengan adanya fonomena ini sebab dengan menggunakan cadar, seorang lelaki sulit untuk dikenali. Selain itu, mereka juga memakai make up layaknya perempuan. Ia dapat dengan mudah melakukan tindak kejahatan dengan memanfaatkan busana perempuan.

Sejak awal, komunitas crosshijabers memang menyukai outfit dan berdandan layaknya perempuan. Fenomena cadar yang kemudian mulai menjadi tren di Indonesia dimanfaatkan oleh komunitas ini. Tidak hanya sekadar melampiaskan perilaku yang menyimpang. Namun, beberapa orang berusaha memanfaatkan tren bercadar untuk kejahatan.

Nena Mawar Sari (antaranews.com, 2019) menjelaskan crossdressing/crosshijabers dalam istilah medis dikenal sebagai transvestitisme, yaitu suatu perilaku yang menginginkan dirinya menggunakan pakaian bertentangan dengan gendernya. Pada mulanya, perilaku ini muncul dari riwayat seseorang yang merasa tidak nyaman dengan identitas gendernya ataupun dari trauma masa lalu.

Crossdressing/crosshijabers, menurut Nena, berbeda dengan transgender. Secara orientasi seksual, mereka memiliki orientasi yang sesuai dengan jenis kelamin aslinya, sementara transgender sebaliknya. Maka dari itu, tujuan dari crossdressing/crosshijabers sendiri bisa saja penyamaran untuk melakukan tindak kriminal, hiburan maupun ekspresi diri, hingga kepuasan seksual (antaranews.com, 2019).

Selain itu, dalam Islam terdapat larangan laki-laki menyerupai perempuan, serta sebaliknya. Larangan ini disebut sebagai tasyabuh (menyerupai) yang meliputi segala kekhasan jenis kelamin, seperti cara berjalan, gaya berbicara, juga berpakaian. Dalam satu riwayat, Ibnu Abbas ra., berkata, "Nabi Muhammad Shallallahu 'alaihi wa sallam melaknat lelaki yang menyerupai perempuan dan perempuan yang menyerupai lelaki” (HR. AlBukhari, No. 5885; Abu Dawud, No. 4097; Tirmidzi, No. 2991) (Annibras, 2017; Wahidin, 2018).

Crosshijabers merupakan fenomena baru, tetapi seluk-beluknya telah ada di masa lalu. Hadis melarang laki-laki berpakaian perempuan. Oleh karena itu, Crosshijabers merupakan realita yang sulit untuk dapat ditoleransi menurut Islam. Informan yang cermat dalam 


\section{Volume: 6 \\ Nomor : 4 \\ Bulan : November \\ Tahun : 2020}

E-ISSH: 2656-940X 글

P-ISSH: 2442-367K

URL: jurnal.ideaspublishing.co.id

menanggapi segala asumsi dari berbagai ranah terutama dalam ranah agama mampu mengimbangi orientasi dari berbagai asumsi yang tabu. Namun, apa dan mengapanya menjadi asumsi umum yang dikembangkan dengan segala perspektif individu.

Fonomena ini tentu saja tidak dapat dibiarkan begitu saja. Perlu ada penanggulangan guna mengurangi penyebarannya sehingga masyarakat tidak diresahkan. Untuk menanggulangi hal tersebut, sebagaimana menanggulangi kasus LGBT, perlu peran, serta komponen-komponen masyarakat, seperti pemerintahan daerah dengan mengadakan sosialisasi, serta membuat kegiatan-kegiatan positif yang mengarah pada pencegahan penyimpangan.

Selain peran masyarakat, peran pendidikan sebagai tonggak pembangunan dan kontrol sosial utama dalam masyarakat, juga dibutuhkan terkait penanggulangan fonomena ini. Untuk itu, kajian tentang pendidikan Islam dalam menanggulangi fenomena crosshijabers menarik untuk dikaji secara detail.

\section{Pembahasan}

\section{Tinjauan terkait Pendidikan Agama Islam}

Pendidikan Islam di Indonesia sebagai bagian dari Sistem Pendidikan Nasional dihadapkan kepada serangkaian kenyataan, bahwa dalam sejarah kemunculannya merupakan respons yang berkembang dan tumbuh dari aspirasi orang-orang Islam yang mengalami tindakan diskriminatif dari pemerintah kolonial Belanda (Choiri \& Fitriani, 2011). Setelah itu, secara berangsur-angsur mengalami perubahan kebijakan dan kedudukan dalam sistem perundang-undangan di Indonesia.

Dalam sistem pendidikan Nasional, Pendidikan Agama Islam terbagi menajdi dua, yaitu berupa Kelembagaan dan Komponen Pembelajaran. Berikut rangkaian UU terkait keduanya dalam UU Sistem Pendidikan Nasional Tahun 2003, sebagaimana telah dirangkum oleh Fathul Jannah (Jannah, 2013).

1. Pasal 1 Ayat (1), pendidikan adalah usaha sadar dan terencana untuk mewujudkan suasana belajar dan proses pembelajaran agar peserta didik secara aktif mengembangkan potensi dirinya untuk memiliki kekuatan spiritual keagamaan, pengendalian diri, kepribadian, kecerdasan, akhlak mulia, serta keterampilan yang diperlukan dirinya, masyarakat, bangsa, dan negara.

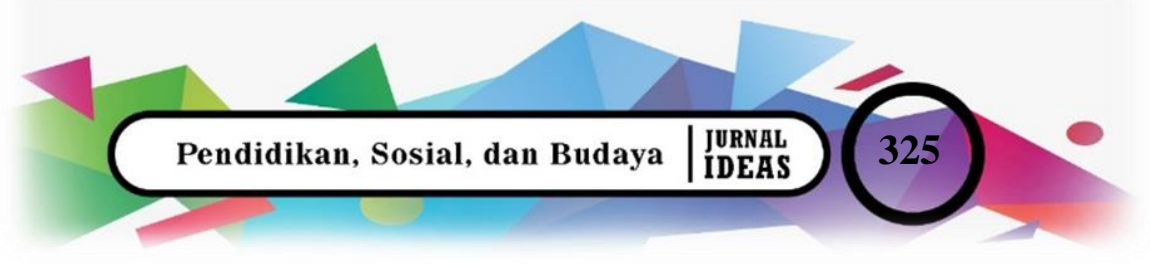


2. Pasal 1 Ayat (2), pendidikan nasional adalah pendidikan yang berdasarkan Pancasila dan Undang-undang Dasar Negara Republik Indonesia Tahun 1945 yang berakar pada nilai-nilai agama, kebudayaan nasional, dan tanggap terhadap tuntutan perubahan zaman. Agama sebagai tujuan pendidikan (agar peserta didik memiliki kekuatan spiritual keagamaan) dan sumber nilai dalam proses pendidikan nasional.

3. Pasal 4 Ayat (1), pendidikan diselenggarakan secara demokratis dan berkeadilan, serta tidak diskriminatif dengan menjunjung tinggi hak asasi manusia, nilai keagamaan, nilai kultural, dan kemajemukan bangsa.

4. Pasal 12 Ayat (1), setiap peserta didik pada setiap satuan pendidikan berhak mendapatkan pendidikan agama sesuai dengan agama yang dianutnya dan diajarkan oleh pendidik yang seagama. Peserta didik berhak mendapatkan pendidikan agama sesuai dengan agamanya masing-masing dan diajarkan oleh guru/pendidik yang seagama. Tiap sekolah wajib memberikan ruang bagi siswa yang mempunyai agama yang berbeda-beda dan tidak ada perlakuan yang diskriminatif.

5. Pasal 15, jenis pendidikan mencakup pendidikan umum, kejuruan, akademik, profesi, vokasi, keagamaan, dan khusus. Pasal 17 ayat (2). pendidikan dasar terbentuk Sekolah Dasar (SD) dan Madrasah Ibtidaiyah (MI) atau bentuk lain yang sederajat, serta Sekolah Menengah Pertama (SMP) dan Madrasah Tsanawiyah (MTs), atau bentuk lain yang sederajat. Pasal 18 ayat (3), pendidikan menengah berbentuk Sekolah Menengah Atas (SMA), Madrasah Aliyah (MA), Sekolah Menengah Kejuruan (SMK), dan Madrasah Aliyah kejuruan (MAK), atau bentuk lain yang sederajat.

6. Pasal 28 Ayat (3), pendidikan anak usia dini pada jalur pendidikan formal berbentuk Taman Kanak-Kanak (TK), Raudatul Athfal (RA), atau bentuk lain yang sederajat. Salah satu jenis pendidikan nasional adalah pendidikan agama. Setingkat Taman KanakKanak (TK) dinamakan Raudatul Athfal (RA), Sekolah Dasar (SD) dinamakan Madrasah Ibtidaiyah (MI), Sekolah Menengah Pertama (SMP) dinamakan Madrasah Tsanawiyah (MTs), Sekolah Menengah Atas (SMA) dinamakan Madrasah Aliyah (MA), dan Sekolah Menengah Kejuruan (SMK) dinamakan Madrasah Aliyah Kejuruan (MAK).

7. Pasal 30 tentang Pendidikan Keagamaan. (1) Pendidikan keagamaan diselenggarakan oleh pemerintah dan/atau kelompok masyarakat dari pemeluk agama, sesuai dengan 
Volume: 6

Nomor : 4

Bulan : November

Tahun : 2020

peraturan perundang-undangan. (2) Pendidikan keagamaan berfungsi mempersiapkan peserta didik menjadi anggota masyarakat yang memahami dan mengamalkan nilai-nilai ajaran agamanya dan/atau menjadi ahli ilmu agama. (3) Pendidikan keagamaan dapat diselenggarakan pada jalur pendidikan formal, nonformal, dan informal. (4) Pendidikan keagamaan berbentuk pendidikan diniyah, pesantren, pasraman, pabhaja samanera, dan bentuk lain yang sejenis. Dalam hal ini, pendidikan agama merupakan tanggung jawab pemerintah dan masyarakat. Di samping sekolah/madrasah formal yang didirikan oleh pemerintah, seperti MIN, MTsN, maupun MAN, masyarakat dapat juga menyelenggarakan pendidikan agama, baik formal (pesantren, madrasah), nonformal (taman pendidikan Alquran (TPA), majelis taklim), maupun informal (madrasah diniyah).

8. Pasal 36 Ayat (3), kurikulum disusun sesuai dengan jenjang pendidikan dalam kerangka Negara Kesatuan Republik Indonesia dengan memerhatikan pada peningkatan iman dan takwa, peningkatan akhlak mulia, dan seterusnya.

9. Pasal 37 (1), kurikulum pendidikan dasar dan menengah wajib memuat pendidikan agama, pendidikan kewarganegaraan, dan seterusnya .... (2) Kurikulum pendidikan tinggi wajib memuat, pendidikan agama, pendidikan kewarganegaraan dan bahasa.

10. Pasal 55 Ayat (1) mengenai Pendidikan Berbasis Masyarakat, menyatakan bahwa Masyarakat berhak menyelenggarakan pendidikan berbasis masyarakat pada pendidikan formal dan nonformal sesuai dengan kekhasan agama, lingkungan sosial, dan budaya untuk kepentingan masyarakat.

Pasal-pasal tersebut merupakan penempatan posisi pendidikan Islam sebagai bagian dalam kerangka sistem pendidikan nasional, bahwa pendidikan Islam merupakan bagian dari sistem pendidikan nasional. Dalam penjelasan Pasal 15 UU Sisdiknas No. 20 Tahun 2003 menyebutkan pendidikan keagamaan merupakan pendidikan dasar, menengah, dan tinggi yang mempersiapkan peserta didik untuk dapat menjalankan peranan yang menuntut penguasaan pengetahuan tentang ajaran agama atau menjadi ahli ilmu agama.

Dari rangkaian di atas, pendidikan Islam mendapat legitimasi untuk eksis dan berkembang di Indonesia, serta termasuk dalam bagian yang integral dari Sistem Pendidikan Nasional guna untuk terpenuhinya kebutuhan pendidikan bagi masyarakat Islam sebagai penduduk mayoritas di Indonesia. Hal ini kemudian menjadikan sistem dan lembaga

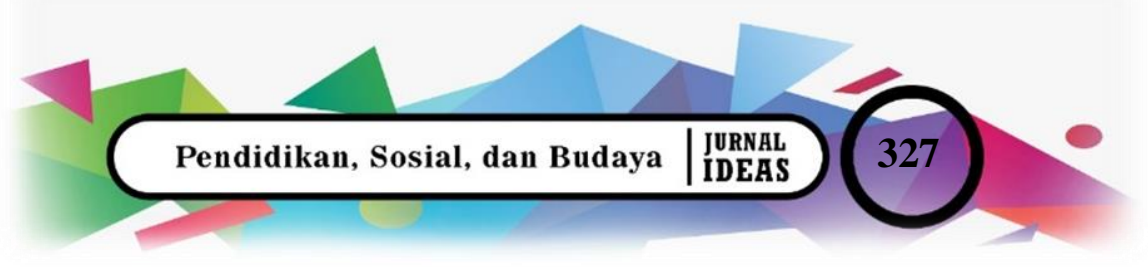


pendidikan Islam memiliki landasan kuat untuk dikembangkan dengan dukungan dana dan atensi dari Negara (Jannah, 2013).

Dengan akamodasi yang telah disiapkan oleh negara untuk pengembangan pendidikan Islam, terdapat tanggung jawab untuk menetralisasi perubahan zaman, memberi arahan terhadap penyimpangan-penyimpangan yang terjadi di masyarakat tanpa melakukan diskriminasi terhadap pelaku penyimpangan.

Terdapat 109.388 lembaga pendidikan Islam yang terdaftar di Indonesia baik berupa pesantren maupun sekolah di bawah kementerian agama (Kemenag, t.t.; Pendis Kemenag, t.t.). Selain itu, terdapat 800 ribu surau/musalah dan masjid yang terdaftar di Indonesia (Rezkisari, 2020), juga terdapat berbagai organisasi masyarakat berbasis Islam yang menjadi basic implementasi pendidikan Islam nonformal di Indonesia. Dengan jumlah akumulasi pendidikan formal dan nonformal tersebut di atas, maka sangat memungkinkan untuk pendidikan Islam mengambil peran, serta dalam menanggulangi penyimpangan yang terjadi, khususnya crosshijabers.

\section{Etika Berpakaian dalam Islam}

Pakaian (Busana) adalah produk budaya, sekaligus tuntutan agama dan moral (AlAlbani, 2010). Alquran dan Sunah berbicara tentang pakaian dan memberi tuntunan menyangkut cara-cara memakainya. Kitab Suci Alquran melukiskan keadaan Adam dan pasangannya sesaat setelah melanggar perintah Tuhan mendekati suatu pohon dan tergoda oleh setan sehingga mencicipinya bahwa:

"(Yakni serta-merta dan dengan cepat) tatkala keduanya telah merasakan buah pohon itu, tampaklah bagi keduanya menutupinya dengan daun-daun surga secara berlapislapis" (QS. Al-A'raf [7]: 22).

Ayat tersebut mengisyaratkan bahwa Adam as., dan pasangannya tidak sekadar menutupi aurat mereka dengan selembar daun, tetapi daun di atas daun sebagaimana dipahami dari kata (yakhshifani) yang digunakan ayat Al-A'raf di atas. Hal tersebut mereka lakukan agar aurat mereka benar-benar tertutup dan pakaian yang mereka kenakan tidak menjadi pakaian mini atau transparan atau tembus pandang. Ini juga menunjukkan bahwa menutup aurat merupakan fitrah manusia yang diaktualkan oleh Adam dan istrinya as. Pada saat kesadaran mereka muncul sekaligus menggambarkan bahwa siapa yang belum memiliki 
kesadaran, seperti anak-anak di bawah umur, maka mereka tidak segan membuka dan memperlihatkan auratnya (Shihab, 2012).

Apa yang dilakukan oleh Adam dan Hawa as., tersebut, dinilai sebagai awal usaha manusia menutupi berbagai kekurangannya, menghindari dari apa yang tidak disukai, serta dinilai buruk, juga sebagai upaya memperbaiki penampilan dan keadaan sesuai dengan imajinasi dan khayal mereka. Itu merupakan langkah pertama umat manusia dalam menciptakan peradaban. Allah mengilhami hal tersebut dalam benak manusia pertama untuk kemudian diwariskan kepada anak cucunya. Jika demikian, berpakaian adalah tanda awal dari lahirnya peradabaan manusia.

Dalam berpakaian, Islam memiliki beberapa batasan, baik untuk laki-laki dan perempuan sebagai penciri untuk gender masing-masing. Perempuan memiliki batasan aurat seluruh tubuh termasuk kepala sehingga kemudian diwajibkan untuk menggunakan penutup kepala atau yang biasa disebut dengan hijab, sedangkan lelaki memiliki batas aurat antara pusar dan lutut. Dari batasan tersebut sudah terlihat jelas adanya perbedaan cara berbusana antara lelaki dan perempuan. Lebih lanjut Ahmad Fauzi (Fauzi, 2016) menjelaskan beberapa aturan berpakaian yang ditetapkan oleh Islam sebagaimana berikut.

1. Perempuan tidak diperkenankan mengumbar aurat. Perempuan dianjurkan untuk berpakaian longgar tanpa memperlihatkan lekuk tubuh, serta tebal yang membuat apa yang ada dibaliknya tidak terlihat. Allah Ta'ala berfirman dalam Alquran surah Al-A'raf ayat 26:

"Wahai anak cucu Adam! Sesungguhnya Kami telah menyediakan pakaian untuk menutup aurat."

2. Busana lelaki tidak boleh menyerupai busana perempuan begitu pula sebaliknya. Dalam Kitab Shahinya, Imam al-Bukhari meriwayatkan:

Dari Ibnu Abbas radhiallahu anhu dia berkata, "Rasulullah shallallahu alaihi wasallam melaknat kaum pria yang menyerupai kaum wanita dan kaum wanita yang menyerupai kaum pria" (HR. al-Bukhari).

3. Tidak merupakan pakaian syuhroh (untuk ketenaran). Dalam sunannya, Imam Ibnu Majah meriwayatkan:

Dari Ibnu Umar radhiallahu anhu berkata bahwa Rasulallah shallallahu alaihi wasallam telah bersabda, "Barang siapa mengenakan pakaian ketenaran di dunia niscaya Allah akan mengenakan padanya pakaian kehinaan di hari kiamat" (HR. Ahmad, Abu Dawud, Al-Nasa'i, dan Ibnu Majah).

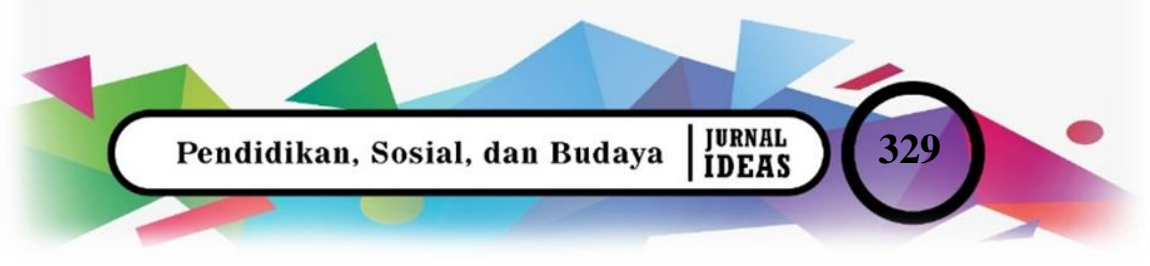


Pada poin kedua di atas dijelaskan bahwa lelaki tidak boleh berpakaian menyerupai perempuan dan sebaliknya. Dalam konteks Islam, hal yang demikian dinamakan tasyabuh. Tasyabuh dalam Islam meliputi penyerupaan dalam hal pakaian, tingkah laku, dan budaya masyarakat (Annibras, 2017). Pada kasus crosshijabers sangat jelas bahwa dalam suatu keadaan laki-laki mencoba menyerupai perempuan dalam berpakaian. Jika dilihat pada etika berpakai di atas, maka hal tersebut dianggap haram secara hukum Islam.

\section{Metode}

Penelitian ini merupakan penelitian kepustakaan dengan pendekatan kualitatif deskriptif fenomenologi. Peneliti berusaha mengkaji teks-teks dan isu-isu yang berkembang terkait crosshijabers, serta kajian teks terkait pendidikan Islam, baik secara formal maupun nonformal guna menemukan peranannya dalam menanggulangi fenomena tersebut.

\section{Peran Pendidikan Agama Islam dalam Menanggulangi Fenomena Crosshijabers}

Sebagai agama mayoritas di Indonesia dengan sekitar 1,5 juta lembaga pendidikan dan organisasi keagamaan, pendidikan Islam dapat melakukan penanggulangan tehadap fenomena crosshijabers dalam dua term. Term pertama dalam lembaga pendidikan formal baik yang berbasis Islam maupun sekolah umum. Term kedua dapat dilakukan melalui kajian-kajian keagaaman yang ada pada masyarakat, baik majelis taklim, selawat maupun pada pendidikan keagamaan (biasa disebut ngaji) di surau/musala.

1. Peran dalam lembaga pendidikan formal

Pada lembaga pendidikan formal berbasis keislaman, pembelajaran agama Islam terbagi dalam lima mata pelajaran, yakni Fikih, Alquran Hadis, Akidah Akhlak, Sejarah Kebudayaan Islam, dan Bahasa Arab.

Pada kajian Fikih terdapat pembahasan terkait aurat. Ketika membahas tentang aurat maka seyogianya dapat dikaitkan dengan batasan-batasan gender dalam berpakaian. Tidak hanya itu, dalam mata pelajaran Alquran Hadis dapat disinggung tentang larangan tasyabuh yang tidak terbatas pada meniru orang kafir belaka, tetapi juga menyangkut pada tasyabuh dalam berpakaian, yang kemudian dapat disertakan dalil-dalilnya. Dalam Akidah Akhlak dapat dibahas pula bahwa penyimpanganpenyimpangan yang terjadi sebagian dari akhlak yang buruk dari akhlak berpakaian, 


\section{Volume: 6 \\ Nomor : 4 \\ Bulan : November \\ Tahun : 2020}

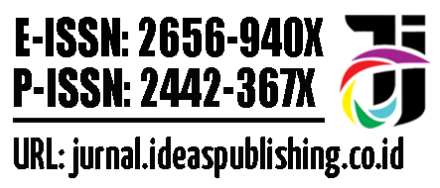

serta akhlak sosial dapat meresahkan pemilik gender yanga asli. Begitu pula dalam Sejarah Kebudayaan Islam mengaitkan tentang kebanggaan lelaki pada pakaiannya.

Dalam lembaga pendidikan umum, pendidikan Islam masuk dalam mata pelajaran Pendidikan Budi Pekerti dan Agama yang memiliki tema-tema integrasi antara kearifan lokal dan nilai keagamaan. Dalam beberapa bab terkait hubungan sosial dapat disinggung terkait penyimpangan crosshijabers dan larangannya.

Pada lembaga pendidikan formal, peran pendidikan agama dalam menanggulangi fenomena crosshijabers tidak hanya di dalam kelas saja. Akan tetapi, juga dapat dilakukan pada kegiatan-kegiataan keagamaan yang ada di sekolah.

2. Peran dalam Lembaga Nonfomal

Dalam dekade terakhir majelis selawat maupun majelis taklim tidak hanya mengumpulkan jemaah lansia, tetapi juga dari berbagai kalangan usia. Hal ini memberi kesempatan besar untuk majelis-majelis ini mengadakan kajian keislaman berbasis fenomena sehingga jemaah yang mengikuti kegiatan dapat mengetahui penyimpanganpenyimpangan yang tidak diperbolehkan dalam agama dan meresahkan masyarakat.

Keberhasilan majelis taklim dalam memberi pengaruh positif dapat dilihat dalam berbagai kajian-kajian terkait majlim taklim yang berjumlah sekitar 6.050 (berdasarkan pencarian di google dengan kata kunci "Majlis Ta'lim). Dalam hal ini, sangat memungkinkan untuk majelis-majelis taklim ini untuk mempengaruhi jemaahnya agar tidak ikut melakukan penyimpangan cara perpakaian.

Selain itu, pendidikan agama di mushalla/surau juga dapat mengambil peran karena pendidikan agama di mushalla/surau mendahului pendidikan formal di sekolah sehingga pendidikan dini dapat dilakukan di tempat tersebut. Selain itu, komunitaskomunitas pemuda muslim juga perlu turut andil dalam menanggapi fenomena ini, dengan mengadakan event-event keislaman kekinian, dengan tema-tema terkait komunitas crosshijabers dan larangan terhadapnya.

\section{Simpulan}

Sebagai agama mayoritas, Islam melalui pendidikannya bertanggung jawab untuk menanggulangi berbagai penyimpangan sosial seperti crosshijabers. Penyimpangan ini selain meresahkan masyarakat terutama perempuan, juga dilarang dalam Islam itu sendiri. Konsep

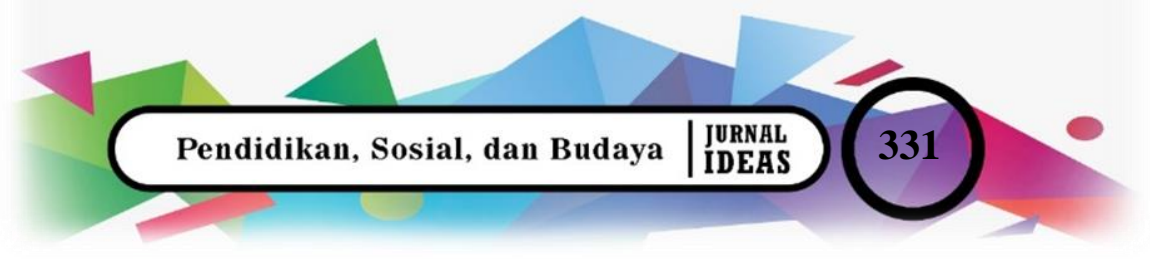


7. E-ISSH: 2656-940X

(1) P-ISSH: 2442-367K

URL:jurnal.ideaspublishing.co.id
Volume: 6

Nomor : 4

Bulan : November

Tahun : 2020

tasyabuh yang terdapat dalil hadisnya dengan jelas melarang penyerupaan laki-laki terhadap perempuan sebagaimana komunitas crosshijabers. Oleh karena itu, pendidikan Islam dapat melakukan penanggulangan dengan menekankan pemahaman terkait pembahasan tata cara berpakaian sesuai gender dengan memanfaatkan lembaga pendidikan formal dan nonformal yang ada di masyarakat yang didasakan pada surat Alquran Surah Al-A'raf ayat 2 yang artinya, "Wahai anak cucu Adam! Sesungguhnya Kami telah menyediakan pakaian untuk menutup aurat," serta dengan menjabarkan hadis-hadis tasyabuh dalam mata pelajaran Fikih dan Alquran Hadis. Penanggulangan ini juga dapat dilakukan dengan mengkaji secara khusus terkait fenomena komunitas crosshijabers dengan berbagai ayat maupun hadis pada komunitas-komunitas keagamaan yang ada terutama komunitas-komunitas remaja.

\section{Daftar Pustaka}

Al-Albani, Muhammad Nashiruddin. (2010). Kriteria Busana Muslimah. Jakarta: Pustaka Imam Asy-Syafi'i.

Annibras, Nablur Rahman. (2017). "Larangan Tasyabuh Dalam Perspektif Hadist." TAJDID: Jurnal Pemikiran Keislaman dan Kemanusiaan, 1(1), 75-96.

Antaranews.com. (2019). "Viral soal 'crosshijaber', Apakah itu?" Antara News. https://www.antaranews.com/berita/1111266/viral-soal-crosshijaber-apakah-itu.

Choiri, Moch Miftachul, dan Aries Fitriani. (2011). "Problematika Pendidikan Islam sebagai Subsistem Pendidikan Nasional di Era Global". Al-Tahrir: Jurnal Pemikiran Islam, 11(2), 303-325.

Fauzi, Ahmad. (2016). "Pakaian Wanita Muslimah dalam Perspektif Hukum Islam." Iqtishodia: Jurnal Ekonomi Syariah, 1(1), 41-58.

Jannah, Fathul. (2013). "Pendidikan Islam dalam Sistem Pendidikan Nasional." Dinamika Ilmu, 13(2), 161-79.

Kemenag, Pdpp. "Statistik data pondok pesantren." Diakses 1 Desember 2020. https://ditpdpontren.kemenag.go.id/pdpp/statistik.

Pendis Kemenag, Emis. "Data statistik madrasah." Pendis Kemenag. Diakses 1 Desember 2020. http://emispendis.kemenag.go.id/dashboard/?content=data-statistik.

Rezkisari, Indira. (2020). "Jumlah masjid Indonesia terbanyak di dunia." Republika. https://republika.co.id/berita/q6d8ij328/jumlah-masjid-indonesia-terbanyak-di-dunia.

Shihab, M. Quraish. (2012). "Jilbab, Pakaian Wanita Muslimah: Pandangan Ulama Masa Lalu dan Cendikiawan Kontemporer". Lentera Hati Group, 1.

Wahidin, Ade. (2018). "Tinjauan dan Hukum Tasyabuh Perspektif Empat Imam Madzhab." Al-Mashlahah Jurnal Hukum Islam dan Pranata Sosial, 06(1), 49-72. 